\title{
Miranda
}

Revue pluridisciplinaire du monde anglophone /

Multidisciplinary peer-reviewed journal on the English-

speaking world

15 | 2017

Lolita at 60 / Staging American Bodies

\section{Singing and Painting the Body: Walt Whitman and Thomas Eakins' Approach to Corporeality}

\section{Hélène Gaillard}

\section{OpenEdition}

\section{Journals}

\section{Electronic version}

URL: http://journals.openedition.org/miranda/10506

DOI: 10.4000/miranda.10506

ISSN: 2108-6559

\section{Publisher}

Université Toulouse - Jean Jaurès

\section{Electronic reference}

Hélène Gaillard, "Singing and Painting the Body: Walt Whitman and Thomas Eakins' Approach to

Corporeality", Miranda [Online], 15 | 2017, Online since 18 September 2017, connection on 16 February 2021. URL: http://journals.openedition.org/miranda/10506 ; DOI: https://doi.org/10.4000/miranda. 10506

This text was automatically generated on 16 February 2021

\section{(c) $(1)$}

Miranda is licensed under a Creative Commons Attribution-NonCommercial-NoDerivatives 4.0 International License. 


\title{
Singing and Painting the Body: Walt Whitman and Thomas Eakins' Approach to Corporeality
}

\author{
Hélène Gaillard
}

\section{Introduction}

It seemed only normal that at some point Walt Whitman, who claimed to be the poet of the body, met painter Thomas Eakins, known for being a careful observer of anatomy. Both living in the Philadelphia/New Jersey area with a similarly complex relationship with their audience, the two men esteemed each other highly. What they shared was a deep fascination for the body and this passion caused them much scandal and disapproval. After they first met in Camden in 1887, Thomas Eakins often visited Whitman both to photograph and paint him. The poet admired Eakins' work and claimed that he "never knew of but one artist, and that's Tom Eakins who could resist the temptation to see what they think ought to be rather than what is" (Goodrich 123). Like Whitman, Eakins was committed to realism and wanted to give a truthful rendition of the human body. Although critics still disagree on this matter (Folsom 1997, 33), photographs from Eakins' 1880s naked series showing an elderly man looking a lot like Whitman seem to indicate that Eakins might have seen everything there was to see about the poet. If those photographs are of Whitman, they are certainly one of the rare examples of pictures of a $19^{\text {th }}$ century writer posing in the nude. But the simple fact that this is an accepted possibility testifies to the poet's unique apprehension of the body. Eakins' own search for the naked truth led him to apply to himself what he taught his students, namely not to be ashamed of one's corporeality, to acknowledge it as man's ultimate truth and to master it so as to better depict it. To the artist, there was "no impropriety in looking at the most beautiful of Nature's works, the naked figure" (Griffin 80). However, his aesthetic principles led him to be expelled from the Pennsylvania Academy of Art in 1886 for having used nude models in his classes. 
2 If Eakins and Whitman had a vision of the flesh that dramatically differed from that of their contemporaries and shocked their audiences, they shared a common understanding of the body and together paved the way for a modern way of looking at physical appearances. The new perception they offered in their artworks also signaled a change in social terms: seen as the epitome of democracy, the flesh and how people thought of it became to them the symbol of equality. This paper will examine the similarities in Eakins' and Whitman's approaches to corporeality and the similar strategy they adopted to impose a new vision of the body in American culture. Although previous research has looked into the connection between the two American artists, this article aims at being a comprehensive study of the resonance of corporeal matters in Eakins and Whitman's art. After focusing on the link between medical progress and the two artists' aesthetics, this study will explore how Whitman and Eakins revised the status of the body in their art and will then analyze how they attempted to give corporeality a new social significance.

\section{Reconsidering the Body}

Starting with the heroic males of $6^{\text {th }}$ century BC Greek art and rediscovered during the Renaissance, the nude in art was challenged in the Victorian age. In the Gilded Age, the depiction of human figures echoed the moral values of modesty and propriety of an era marked by scientific progress and looking for self-improvement. Nudity was hence rare in the American art of the second half of the $19^{\text {th }}$ century. However, as the classical ideals of perfection and order defined a proper manner of representing bodies, a distinction between nudity and nakedness ${ }^{1}$, sensuality and pornography was made in order to continue enjoying human forms. In 1884, a New York court ruled that "mere nudity in painting or sculpture is not obscenity," but the Woman's Christian Temperance Union still pressured art institutions into rejecting all kinds of representations-be they nude or naked-in art (Parker 114). Even though disclosing the reality of the human body was the object of the period's scientific study, the Victorian approach to corporeality was still highly conservative and did not benefit from the redefinition of biology promoted by scientists. Major advances in medical science occurring throughout the $19^{\text {th }}$ century marked the beginning of modern medicine. Charles Darwin's breakthrough in biology changed the way people perceived the supremacy of the human being, Louis Pasteur proved that microorganisms could cause diseases, and Claude Bernard introduced the careful observation of pathology thus ensuring scientific objectivity in the medical field. These groundbreaking discoveries altered the romantic and religious apprehension of the body. Moreover, the development of new medical tools such as X-rays to facilitate surgery triggered the idea that bodies, just like machines, could be fixed if one had the right instruments. Although the main contributions came from Europe and more particularly from France, significant advances occurred on the other side of the Atlantic. The discovery of anesthesia in Boston in 1846 was a major achievement that turned European attention to American practices. Major innovations equally happened during the Civil War, which allowed a better treatment of gunshot wounds and the development of medical statistics and records (Porter 154-202).

Unsurprisingly, both Whitman and Eakins carefully followed the development of science and they translated their interest into their works. In a study of the poet's 
curiosity for science, Harold Aspiz extensively surveyed the various sciences that influenced Whitman's thinking (Aspiz 216-232). To some critics, Whitman's approach to science was hindered by his religious faith and his beliefs in pseudoscience. Yet, his consideration for an empirical method led him to praise scientific principles: "Hurray for positive science, long live exact demonstration!" (LG 25) Whitman pays tribute to science in Leaves of Grass which he acknowledges in a letter to naturalist John Burroughs as "the first attempt at an expression in poetry [...] to give the wonder and the imagination a new and true field-the field opened by scientific discovery" (Burroughs 56). As a self-taught man, Whitman got acquainted with science through popular articles and his journalistic work sometimes included reviews of new discoveries among which Alexander von Humboldt's Cosmos: A Sketch of the Physical Description of the Universe (1845), N. F. Moore's Ancient Mineralogy (1859), George Combe's The Principles of Physiology (1836), William Paley's Natural Theology (1809) and Elias Loomis' Elements of Natural Philosophy (1859) (White 7-30). To Stovall who also studied Whitman's scientific contribution, "there is no evidence in the poems of the 1855 edition that anything more than the romance of science had interested him seriously" (Stovall 153). It can be objected that Whitman's consideration of science remained auxiliary as exemplified by his conclusion that "scientific facts are useful yet they are not my dwelling" (LG 25). Yet, the body, medicine and biology were fields that deeply concerned him and were in fact his dwelling; as such, they significantly permeated his art. This approach is also central in the evaluation of Whitman's placement within the romantic tradition. It testifies to the poet's will to assign an American character to romanticism so as "to give something to our literature which will be our own." In this case, it was the consideration for science and empirical observation that shaped the transcendentalist nature of Whitman's poetry. Devoted to the understanding of the human body, Whitman deplored the horrors of primitive surgery in his journalism. He strongly supported the evolution of medicine that protected the integrity of the "sacred" body by avoiding amputation and monitoring deliveries. His volunteer service in hospitals during the Civil War reinforced his beliefs in the urgent need for medical progress. The poet's fascination for the sacredness of the body is extensively voiced in Leaves of Grass: as the only poetic work of its era that refers more than two hundred times to the body and includes a full description of body parts, the collection of poems testifies to Whitman's position as the poet of the body, if not the medicine poet. This peculiar stance for $19^{\text {th }}$-century poetry was also evidenced by the illustration for the original edition, a photo engraving depicting a relaxed middle-aged man who shared nothing with the superior, intellectual beings poets were supposed to be. From the first few lines, Whitman's poetic persona makes it clear that Leaves of Grass is corporeal poetry: it is not sung by a voice but expressed through the physicality of the tongue. Reading Whitman's poetry aloud requires practice with all mouth muscles. From the first stanza of "Song of Myself," the poet's use of repetition (myself-assume) and alliteration (spear-summer-grass) ensures fluidity as well as a sound-conscious reading. Its rhythm is accordingly natural and breaks free from the artificiality of traditional stanza forms and rhyming patterns. If the soul is invited, "Song of Myself" is beforehand a celebration of the body (LG 2). Concerns about health appear from the very first page as shown by the mention of "37 years old and in perfect health" (LG 1) and they are recurrent throughout the poems with references to amputations, pains, illnesses and childbirth. The concluding section of "I Sing the Body Electric" is a 36-line catalogue with more than one hundred bodily parts, from head to toe, ignoring neither 
"bowels," nor male and female genitals. Many among Whitman's contemporaries including his fervent supporter Emerson disliked this section and encouraged him to remove it, as they could see no point in such a literal enumeration. But Whitman objected and his refusal indicates how important this naturalist section was to him and to his readers: not only does it pay tribute to the finest pieces of natural creation but it also forces readers to reconsider their corporeality as it introduces some essential biological knowledge. Every single element of what constitutes "the meat of the body," as Whitman puts it, shares equal importance in this list: they function as a whole and none must be disregarded.

5 Eakins' own preoccupation for anatomy and the inclusion of this knowledge in his painting served the exact same aesthetic and didactic purposes. If it is said that the painter contemplated becoming a surgeon, his passion for the reality of the human body is beyond doubt. Along with his training in anatomy at the Pennsylvania Academy of Fine Arts, Eakins also attended medical courses in anatomy and dissection at Jefferson Medical College. His intention was to improve his artistic skills since as he stated to William C. Brownell in an interview, "one dissects simply to increase his knowledge of how beautiful objects are put together to the end that he may be able to imitate them" (Brownell 745). Eakins' singular realism ${ }^{2}$ combining his interest for all types of subject matters and his use of modern tools (photography, motion study) came from his fascination for the flesh and what lies beneath it. To John Updike, "nudity and verity were linked with an unusual closeness" (Updike 80) in Eakins' mind: realism had to be linked to an extensive knowledge of the human form. If he accurately rendered corporeality in his paintings and was one of the first artists to use photography, Eakins also strived to modify the perception people had of the body. Linked with his own training in medical sciences, his masterpiece The Gross Clinic (1875) staging Dr. Gross operating and teaching at the same time contains what it takes to change one's perception of the body. Painted on the occasion of the centennial and conceived to promote medical progress, The Gross Clinic was dismissed for being obscene and disturbing. The reason why it was deemed improper for an exhibition in the centennial was not simply because it depicted open surgery. In The Gross Clinic, Eakins exhorts viewers to take a look at something hardly understandable at first sight: what exactly is going on the operating table is not immediately clear. To be able to make sense out of it, spectators need to carefully observe the visible parts of the patient who is reduced to an exposed buttock and thigh. In a comment for the New York Tribune in March 1873, an art critic noted the effort required from the viewer to examine the patient's body: "a long and shapeless lump of flesh which we conclude to be a thigh" (Burns 190). In other terms, the public must act as anatomical students to reconstruct the scene, hence mirroring the own figure of the artist who painted himself in the bottom right corner of the audience. What one understands after complete examination is that the team of surgeons makes an incision in the patient's thigh while another conducts the anesthesia by applying chloroform to the patient's face. Known for being a specialist in conservative surgery, Dr. Gross and his assistants are saving the patient's limb from amputation by curing a bone infection. Another example of the specular and anatomical challenge Eakins placed in the painting is the woman with clawing fingers. As her face is turned aside, it is the study of her fingers that can only help to comprehend the scene. Showing tension and anxiety, her twisted fingers indicate that she obviously shuns from the sight of the operation and might be close to hysteria. The proximity with Dr. Gross's steady hand contrasts with the woman's fingers and 
emphasizes the absence of control from the female figure's part. Seemingly too emotional, she misses the opportunity to look at the body being operated and "can't aid with wringing fingers," a posture that recalls the vain gesture of assistance of Whitman's poetic persona in "The Sleepers." According to Eakins, just like art, knowledge and science primarily involve careful observation: this fact seems to be the underlying message in The Gross Clinic. It is highly significant that Eakins offered a print version of The Gross Clinic to Whitman soon after they first met. Indeed, the picture stages their ultimate goals: preserving the integrity of the body and forcing viewers to rethink the human form.

Originally meant to celebrate progress at the Centennial Exhibition, the painting was certainly meant to provoke a strong reaction. If it was initially dismissed, after some reconsideration the jury accepted Eakins' work in the Exhibition's medical pavilion. By doing so, they denied Eakins' work its artistic value and paved the way for more negative criticism such as the review for The New York Times in 1879: "The ugly, naked, unreal thigh ... the spurting blood ... are bad enough.... This violent and bloody scene shows that at the time it was painted, if not now, the artist had no conception of where to stop. Power it has, but very little art" (Homer 81). The Gross Clinic was only envisaged in terms of scientific observation and was denied any artistic relevance. As Ruth L. Bohan stated, "the effective denial of the painting's art value echoed the challenges to the literary merits of Whitman's verse" (Bohan 113). What commentators said about Leaves of Grass-[Whitman's] words are quite out of place amid the decorum of modern society" (Dana 3) or "We are bound in conscience to call it impious and obscene" (Alger 471)-strongly recalls the criticism Eakins received for his paintings. Whitman and Eakins certainly wanted to shock, that is to say, to surprise and disturb but they also had didactic purposes in mind as they wanted to educate their audience to a modern way of looking at bodies. Both saw their work and artistic identity questioned on account of their artistic and pedagogical motives. Because they suggested a new way of considering the body as a whole made of different parts whose surface could reveal the inside, they were censored in their pursuit of corporeal and spiritual realism.

\section{Re-Presenting the Body}

7 To Eakins and Whitman, the body was not the enemy of the soul, nor should it have a second-rate status. The two artists challenged the predominant $19^{\text {th }}$-century idea that established the superiority of the spirit, as opposed to the so-called baseness of physicality. They developed an approach to corporeality that deeply associated body and soul. In the conclusion to his long list of body parts in "I Sing the Body Electric," Whitman's poetic persona states that "O I say these are not the parts and poems of the body only, but of the soul, O I say these are the soul," thus establishing a link between spirituality, creativity and the body (LG 104). Eakins and Whitman's efforts to scrutinize outward appearances are related to their beliefs that the flesh was connected to the spirit.

8 Whitman's poem "Faces" accounts for the possibility to read physical features and to determine the essence from the observation of surfaces. If faces-the only part of the body fully disclosed to others-can provide insight into the inner soul, they require the ability to interpret signs. Trained from an early age as a typewriter, Whitman was well experienced in the reading of signs. In Walt Whitman's Faces: A Typographic Reading, 
Barbara Henry interprets "Faces" as a poem based on double entendre in terms of types and fonts and thus, suggests Whitman's deep interest in semiology (Henry 8). Whitman was well aware that judgment stemming from beauty would fail as "the ugly face of some beautiful soul" was no exception but he "was not tricked by it" (LG 107). Knowing that the poet was familiar with phrenology can also explain his insistence on the shape and size of facial types: the reason why he paid so much attention to "the grand faces of natural lawyers and judges broad at the back top" and "the faces of hunters and fishers bulged at the brows" (LG 105), is certainly because he was well acquainted with the pseudoscience that focused on the skull area to determine personalities. In the late 1840 s, Whitman turned to phrenology, a theory stating that each human functionphysical, sexual, moral, social, and spiritual-corresponds to certain brain areas so that the measurement of how the skull protrudes defines characters. One should bear in mind that, at the time, scientists had not yet dismissed phrenology and many believed it could cast light on some physiological and psychological truth. However, Whitman's interpretation of bodies was not limited to reading the skull and relied instead on a diversity of mechanisms as exemplified in "I Sing The Body Electric":

The expression of a well-made man appears not only in his face,

It is in his limbs and joints also, it is curiously in the joints of his hips and wrists,

It is in his walk, the carriage of his neck, the flex of his waist and knees, (LG 95-96)

The title of the poem itself shows the importance of another scientific phenomenon in the understanding of corporeality. Electricity had intrigued scientists and the general public from the past centuries and Benjamin Franklin, among others, had contributed to a better comprehension of its functioning and use. In 1791, Italian physician Luigi Galvani introduced the principle of bioelectricity by proving that electricity was the medium by which nerve cells passed signals to the muscles. Whitman's poetic imagery is based on the assumption that the body is in essence electric and that each of its components is driven by energy and generates magnetism. In a sense, it was proof that the flesh and the mind were connected. Whether it takes the form of an inner fire, a sexual drive or magnetism, electricity-this invisible and mysterious force-could unlock the secrets of humankind. The ultimate power of the body comes from its ability to connect to other bodies, and to breed others, a wonder that Whitman carefully examines in his poetry throughout the many references to sexual intercourse and reproduction. In "Song of Myself," he refers to the principle of bioenergy that connects his own body to the world through "conductors," associating sensations and sciences: "Mine is no callous shell, I have instant conductors all over me whether I pass or stop, They seize every object and let it harmlessly through me" (LG 31). As it was seen as setting the body into animation and potentially producing more bodies, electricity was indeed related to the anima, the soul. As such, the flesh appears most expressive when bodies are in motion and reveal their sacred connection to the spirit. The bodycentrism that Whitman advocated focuses less on resting than on moving bodies. While the persona is at times static, lying on the grass or sitting, the people are mostly portrayed in action, at work or involved in physical activity. If Whitman considered the body as the most beautiful object, he also strongly advocated exercising as expressed in "Democratic Vistas" (1871): "[A] clear-blooded, strong fibred physique, is indispensable" or in "I Sing the Body Electric," "And in man or woman a clean, strong, firm-fibred body, is more beautiful" (LG 102). In "The Sleepers", the description of the "beautiful gigantic swimmer swimming naked through the eddies of the sea" (LG 88) 
voices the poet's belief that physical strain-itself related to beauty-can also bring out the best qualities of the soul: courage, self control and determination.

Strikingly similar connections between the body and the soul were established in Eakins' paintings. He, too, was fascinated by the opportunity to read the soul through the body and to observe corporeal motion and energy. One of the aesthetic principles at work in Eakins' work is the faithful rendering of his sitter's outer appearance. Contrary to most of his contemporaries, he never tried to alter physical features so as to enhance the beauty of his models. Eakins did not strive to paint a younger or healthier Whitman but his uncompromising realism certainly brought out the type of beauty that both the painter and the poet associated with old age. In Eakins and Whitman's thinking, an aging body was not the sign of decay or corruption. To the contrary, it signals "a wonderful vigor, calmness, beauty of person" as expressed in Whitman's own poetry. The portrait Eakins painted of the poet matches Whitman's description of the venerable farmer in "I Sing the Body Electric":

I knew a man, a common farmer, the father of five sons, [...]

This man was a wonderful vigor, calmness, beauty of person,

The shape of his head, the pale yellow and white of his hair and beard, the

immeasurable meaning of his black eyes, the richness and breadth of his manners, (LG 97)

11 In the painting, the emphasis on the upward movement of the eyebrows counterbalancing the drooping eyelids implies the old man's inner strength. After the poet died, Eakins made a death mask and hand cast of Whitman with the help of his assistant Samuel Murray. The painter's fascination for Whitman's facial features and body parts unveils his desire to capture the essence of his being. Eakins' anatomical knowledge and commitment to corporeal authenticity led him to focus on minute details, which often ended in aging his sitters. To Elizabeth Johns, "a room full of Eakins' portraits is a room full of prematurely older sitters, of paintings almost like Wilde's storied portrait of Dorian Gray, that showed what the living physiognomy did not yet reflect" (Johns 1991, 163). In many cases, the portraits never fully appealed to the person they depicted. For instance, Robert C. Odgen, an influential businessman and philanthropist, was extremely dissatisfied with his portrait and eventually decided to return the art to Eakins' studio. As a result, the Philadelphian artist was far from being as popular as Sargent ${ }^{3}$ and was rarely commissioned for bourgeois portraiture. Out of the 247 paintings he completed, only 25 were commissioned. But if his body of work was rather limited, Eakins could choose to paint whoever he thought were interesting subject matters and often turned to people he knew personally or professionally.

12 A closer look at the portrait he painted of his own wife Susan exemplifies what has been referred to as Eakins' psychoanalytical portraiture but testifies more to the painter's commitment to realism and his effort to make the body match the soul. Many critics look at Eakins' portrait of his wife Portrait of the Artist's Wife and Setter Dog (1884-1889), completed only a few years after they got married, as unromantic and wonder about the reality of his feelings for her. Painted during the troubled time when Eakins was dismissed from the academy, faced multiple accusations and caused scandal in his wife's family circle, the portrait is certainly an accurate representation of her nervous state. Her face is emaciated, her eyes are two small black holes and the dark circles under them signal extreme fatigue. Her left hand lies listlessly, palm up and curled fingers while her shoulders sag. She appears frail and the light blue color of her 
dress makes her recede even more. The dog lying at her feet mirrors her nervous exhaustion. Everything in her body language and facial features expresses lethargy. An 1886 photogravure of a previous version proves that Eakins reworked his wife's portrait and emphasized the impression of frailty. The fact that she is directly looking at the viewer is a configuration that was uncommon in Eakins' works; it might imply a sense of guilt from the artist who felt responsible for the household's troubles. By accentuating her tiredness and aging her, Eakins completed a portrait of unflattering realism but he certainly reached his goal as he gave insight into her psychological state as well as his own distress. Contrary to Whitman, Eakins was not directly influenced by phrenology. However, after his training by French artist Jean-Léon Gérôme, who was famous for his typified characters, Eakins was receptive to the principles of physiognomy. Still, he adapted the theory by suggesting a link between outer physique and inner psychology.

Even though many portraits completed in this period exemplify neurasthenia, Eakins was also obsessed with bodies in motion. According to Johns, this was certainly the reason why he aged his models: 'in a profound sense Eakins' aging of his sitters is related to the preoccupations of other artists with change and with motion" (Johns 1991, 164). Contrary to the soul, the body, which is a moving object, is primarily subject to change and alteration. And just like Whitman, Eakins seemed to believe that interestingly, active bodies also accounted for the spiritual. The body in motion could tell about its inner drama as expressed in Whitman's "I Sing the Body Electric" where men and women are examined as they linger, pass by, swim, bend, march or wrestle. If Eakins was already well trained in the possibility of movement through anatomy, he also pioneered in the artistic use of photography so as to observe the actual body motion. Only a few artists of his time considered the advantages the camera could offer and many traditionalists simply rejected the inclusion of a machine into art. Whitman was among the few who praised the use of photography and acknowledged its artistic value, as stated by Roberta K. Tarbell:

Whitman related to the new art of photography in several ways: as the natural media to serve democratic ideals, as an apparently realistic form of art relatively free of traditional affectations that he could use and did use as model to construct his poems (a new way of seeing), and as the format he preferred for portraits of himself. (Tarbell 167)

As for Eakins, if he continued to favor painting from the living model, he made extensive use of photography to capture the body's movements. Introduced to motion photography by Eadweard Muybridge in the late 1870s, Eakins was interested in precision measurements on a single image. This was particularly useful in his representations of athletes, a subject matter that had been a preoccupation all along his career and led him to depict rowers, swimmers, wrestlers, boxers and dancers. If some critics relate Swimming Hole (1885) to section 11 of "Song of Myself" (Johns 1996) or the recount of the swimmer in "I Sing the Body Electric," the painting can be primarily looked at as a study of body movement, a pictorial translation of motion photography including different stages of action and time. Eakins' depiction of sculling -a subject for which he is uniquely identified in the early 1870 s and was familiar with as an amateur oarsman-signals his obsession with the representation of moving bodies, strained muscles but also mental force. In The Biglin Brothers Racing (1873), the emphasis is on coordination, muscular exertion and physical strength but the viewers also get the sense that what animates the duo reaches beyond the physical: the sense of 
urgency created by the extension of the scull boat out of the picture frame and the appearance of another boat visible on the right is evidenced in the way the brothers look. Although this painting celebrates physical prowess, it also emphasizes the mental strength that sets the body in motion and makes it surpass its abilities. Willpower is also evidenced in Eakins' famous painting The Champion in his Single Scull (1871). More ambivalent as it opposes motion and stasis, the scene painted to commemorate Schmidt's victory paradoxically focuses on resting after practice time. The unique position of the athlete's body, looking back over his right shoulder to face viewers, gives evidence of Eakins' interest in anatomy but also serves to render the moment of quiet introspection. It is a peaceful time when his body and his mind are equally at rest. Blinded by the light, the champion frowns and slightly closes his eyes. Reacting to external influence, his bodily reaction and his desire to be in the spotlight serve as a reminder of what might animate the champion's body during a race: dignity, peer support and self-accomplishment. Hence, not only did Eakins and Whitman revise the status of the body by showing its correlation with the spirit, but they also offered the sense that because it could be exercised, mastered and improved, it was the primary organ of democracy.

\section{Re-Empowering the Body}

15 As Ed Folsom pointed out in a lecture delivered in 1998 "What Do We Represent? Walt Whitman, Representative Democracy and Democratic Representation," to Whitman, "Democracy begins with the body, because the place to begin to break down the distinctions [...] was in frank recognition of the physical urges we all shared" (Folsom 1998). Eakins also posited that the body is an agent of democracy and equality since it can be modeled so as to turn the common man into an uncommon one. On canvas and in poems, both artists memorialized their own diversity of America: rowers, teachers, actresses, anthropologists, cowboys, dancers, men as well as women, often white but also black. Whitman's inclusion of types was even wider "all men in all ages and lands" (LG 19), and he saw no distinction between men and women, as expressed in, "The body itself balks account, that of the male is perfect, and that of the female is perfect" (LG 95). His vision of humanity is truly equalitarian whereas the painter enhances the common man turned uncommon. Belonging to two different social classes, they had a different conception of democracy: Walt Whitman was self-educated and the son of a working class family from Long Island, whereas Eakins' world was the Philadelphian professional upper-middle class. Undeniably, as art critic Lloyd Goodrich pointed out, "Both were democrats despising forms and conventions which hid the essential human being" (Goodrich 122), but one main difference must be taken into consideration: Eakins praised individuality and merit, while whitman favored the whole of mankind and inherent equality. John Updike equally noted this major difference and claimed that "Whitman had a great subject: New York City, melting pot of an immigrant democracy. Eakins had, instead, troubled faces of the Philadelphia gentry" (Updike 80). But in any case, to both artists, democracy stemmed from the body.

In the 1870s, Eakins was one of the few painters to consider black people without artistic prejudice or condescension. The Dancing Lesson (1878) testifies to Eakins' progressive thought and more equalitarian standpoint. The painting considerably differs from the depiction of black people rehearsing for or performing in a minstrel 
show. The interior scene painted with watercolor is not characterized by glee, humor and ignorance. To the contrary, the three men are deeply focused showing efforts, rigor or analysis, a fact that is observable by paying close attention to their bodies. Belonging to three different generations, they are all engaged in a profoundly formative act of instruction, a transmission of personal experience from one generation to the next. To Eakins, this only could grant merit and proved equality. The older man's posture, standing and observing the boy with care while following the rhythm with one foot puts him on a par with others of Eakins' great teacher figures such as Dr. Gross. His being dressed rather formally in a vest and short jacket with his top hat and cane on the chair near him adds to his dignified position as a dancing master and reminds of Eakins' depiction of his own father watching over his two friends in The Chess Players (1876). The seated black youth playing the banjo with his head inclined toward the dancing boy is also fully focused, but the most interesting figure of the group is the younger boy. Holding his head high while striving to move with the music, his knees bent and his feet raised on his toes, he embodies Eakins' vision of modeling and controlling the body so as to connect with others and share emotions. The presence of the well-known photograph showing Abraham Lincoln and his son Tad examining a book on the wall in the upper-left corner establishes a link between freedom and instruction and a connection between black and white lives. If this reference could also be regarded as a patronizing gesture, this painting points to Eakins' belief in the power of the body to assert one's place in society. Democracy-the power to the people-derives from the power of bodies. Eakins' somacratic ${ }^{4}$ vision includes both intellectual and physical values. In this respect, his admiration for surgeons can be better understood for they embody both intellectual and manual accomplishments and share their skills and knowledge. Eakins' praise for medical doctors as democratic agents is also certainly the reason why he chose to depict Dr. Gross, a local surgeon from a middle-class background, not directly performing surgery but sharing his knowledge and techniques as he acted democratically to improve both the body and spirit of man. Through this imagery, he also placed his work within the tradition established by Rembrandt's The Anatomy Lesson of Dr. Nicholas Tulp (1632) but with a heightened sense of drama and a broader inclusion of medical students. Eakins' sense of democracy seems mostly based on the principle promoted in the $18^{\text {th }}$ century by his fellow Philadelphian Benjamin Franklin advocating the equalitarian form of government as an opportunity for self-improvement. The underlying idea was that although all men are created equal, they should cultivate their own body and soul so as to become virtuous, strong and talented human beings. Franklin was himself inspired by John Locke's discussion of political rights and educational theories dating back to 1690 (Power 104). In the Second Treatise of Government, Locke writes "God gave the world to men in common; but since he gave it them for their benefit, and the greatest conveniences of life they were capable to draw from it, it cannot be supposed he meant it should always remain common and uncultivated" (Locke 21). Eakins' realistic treatment of the flesh was positively modern; yet, early $18^{\text {th }}$ century ideology still inspired his democratic views.

If, to Eakins, democracy implies the equal right to spiritual and corporeal development, Whitman's poetic persona does not set any physical or intellectual standards as shown in the opening of "A Song for Occupations":

Is it you that thought the President greater than you?

Or the rich better off than you? or the educated wiser than you? 
(Because you are greasy or pimpled, or were once drunk; or a thief,

Or that you are diesel'd, or rheumatic, or a prostitute,

Or from frivolity or impotence;

Or that you are no scholar and never saw your name in print,

Do you give in that you are any less immortal? (LG 68)

From Whitman's perspective, the simple fact of having a body grants universal equality: "I speak the password primeval, I give the sign of democracy." The meaning of "password primeval" has been discussed by many scholars since its meaning can include references from ancient history to mysticism. However, what seems of greater interest is the concrete terms in which democracy is established: it is based on visual, tactile and oral capabilities. Expressed in such material terms, it seems that the representamen-the element that can signify its object by the principle of repetition in Charles S. Peirce's semiotic theory-of democracy is the body (Peirce 87). As human beings are composed of the same material substance, they are naturally granted equality: "By God, I will accept nothing which all cannot have their counterpart of on the same terms" (LG 26). Whitman offered an understanding of democracy that challenged the traditional interests of the individual and the collective to make them identical: "O my Body! I dare not desert the likes of you in other men and women, every atom belonging to me, as good belongs to you" (LG 28). The human form does not involve hierarchy as proved by the long lists of bodily organs given in no particular order. Because the well-being of the whole body relies on the functioning of its components, corporeality is indeed a sign of democracy: "Not an inch nor a particle of an inch is vile, and none shall be less familiar than the rest" (LG 4). It necessarily rejects the idea of superiority or hierarchy and serves to signal the necessity of democracy. To Whitman, because the personal is collective, it is also political: his conception of the body politic linked the political body with the intimate body in an inextricable way. Not only does the episode of the slave auction in "I Sing the Body Electric" expose a personal corruption of the body but it also casts light on a flawed political system: "If any thing is sacred, the human body is sacred, And the glory and sweet of a man, is the token of manhood untainted" (LG 102). Again, the term "token" which connotes the materiality and spiritual meaning of a sign places Whitman's poetry in accordance with Peirce's semiotic findings. ${ }^{5}$ Following the American philosopher's theory and Whitman's thinking, the body is a sign that operates at the three levels of significance: having a likeness with all bodies, it is an "icon" for the human form; in virtue of its causal connection with similarly shaped beings, it is an "index" of equality and it is finally a "symbol" of democracy after Whitman posited its universal value. Although sharing seemed crucial in Whitman's appreciation of human integrity, the poet also insists on the idea of corporeal freedom and the impossibility to own another person's body: "let the slaves be masters, I say man shall not hold property in man." His poetic persona acts precisely as a body able to reconcile both parties. In the manuscript of an early version of "Song of Myself," Whitman inscribed the desire to embody true democracy through a new vision of corporeality. The poetic persona has the ability to stand between opposites so as to unite and merge slaves and masters:

I am the poet of the body

And I am the poet of the soul

I go with the slaves of the earth equally with the masters

And I will stand between the masters and the slaves,

Entering into both so that both shall understand me alike. (Whitman 1855) 
The homoerotic subtext of these lines foreshadows the Calamus poems and reminds of Eakins' statements, such as "She [the female body] is the most beautiful object there is except a naked man" (Griffin 80) that revealed his homophile sensibility. But Eakins made clear in a letter to Edward H. Coates dated 1886 that gender or sexual questions should not compromise the celebration of bodies: "Should men make only the statues of men to be looked at by men while the statues of women should be made by women to be looked at by women only? Should the he-painters draw the horses and bulls, and the she-painters like Rosa Bonheur the mares and the cows?" (Werbel 83). Regardless of their orientations, it is clear that Whitman and Eakins advocated the celebration of all bodies, therefore hinting at the possibility of sexual attraction and homosexual desires. Eakins' arcadia pictures in the vein of Swimming Hole or Arcadia (1883) rely on the Greek ideals of male comradeship, physical beauty and athletic bodies. Indeed, this classical style derived from a democratic empire could easily be transferred to $19^{\text {th }}$-century American bodies. Yet, within their new American context and considering Eakins' frank realism, his paintings representing nude males were mostly seen in a homoerotic light, putting aside the somacratic discourse. If the importance of the sexual aspect of Whitman's poetry is undeniable, the sexually charged Calamus poems were claimed to be political by its author. They are for sure both, as the love for all bodies and the interconnectedness of human forms are equally essential in Whitman's definition of democracy as well as in Eakins'. The basis for democracy is to be found in the full acceptance of the body and the recognition of "the need of comrades," a principle that can be visible in Eakins' paintings The Gross Clinic or Swimming Hole and in Whitman's poetry. Based on a diversity of male friendships, Whitman starts the fifth section of "Calamus" by showing that the ideal state of democracy-not yet reached in the America of the Gilded Age-will stem from the natural connection all human beings experience, as the bond between people is primarily physical.

There shall from me be a new friendship

It shall be called after my name,

It shall circulate through The States, indifferent of place,

It shall twist and intertwist them through and around each other

Compact shall they be, showing new signs,

Affection shall solve every one of the problems of freedom,

Those who love each other shall be invincible,

They shall finally make America completely victorious, in my name. (Whitman 1855)

\section{Conclusion}

To conclude, it is clear that because Whitman and Eakins were ahead of their time, they could not develop their corporeal aesthetics to a full extent. If they supported each other, they were rather isolated in the art world. That is probably one of the reasons why they constantly revised their works: Whitman never published many of his original lines and kept re-editing his Leaves of Grass throughout his life. The ceaseless manipulations of the poems from the first edition in 1855 to the deathbed version of 1892 imply that Whitman conceived his poetry as a body per se, one that he needed to model so as to make its appearance more acceptable. His statement about the "new and 
much better edition of Leaves of Grass complete-that unkillable work" (Reynolds 474) he finished in 1867 indicates the anthropomorphism of Leaves of Grass.

Similarly, Eakins sometimes conceived different versions of the same paintings to avoid scandal. The evolution in the versions Eakins painted of William Rush and his modelalso known as William Rush Carving His Allegorical Figure of the Schuylkill River-testifies to the progressive awareness of corporeality. In the first painting he produced in 1876-77 on this subject matter, the attention was on the female body represented as a hybrid form of abstract feminine ideal and realistic female beauty as made visible by the two different ways of painting her skin. The sculptor himself stands in the dark background, making clear that he is not the main focus of interest. In this early version, Eakins had already failed to contextualize his female nude, provokingly drawing the clothes she had taken off in minute details in the foreground. To a commentator for The New York Times, this "ruined the picture" for the "presence in the foreground of the clothes of that young woman, cast carelessly over a chair [...] gives the shock which makes one think about the nudity-and at once the picture becomes improper" (Sewell 45). The version Eakins completed in 1908-and which happens to be one of his last paintings-proves that, by the end of his career, the artist felt that the early $20^{\text {th }}$ century public was more willing to face the reality of the body. He ultimately refused to "mutilate" the female body and reached full body disclosure by favoring a frontal angle of the woman's anatomy including her face and her pubic hair. Comparatively, Eakins received less negative reviews for this much bolder depiction of Rush and his model. As Western societies continued to revise their judgment on bodies, Eakins and Whitman's legacy was gradually revived. In the 1950s, the Beat Generation paid tribute to Whitman's corporeal approach and by the end of the 1980s, Eakins eventually emerged as a major figure in sexuality and gender studies.

\section{BIBLIOGRAPHY}

Alger, William. "Review of Leaves of Grass." The Christian Examiner 60 (1856): 471-473.

Allison, Raphael C. "Walt Whitman, William James, and Pragmatist Aesthetics." Walt Whitman Quarterly Review 20 (2002): 19-29.

Aspiz, Harold. "Science and Pseudoscience." In A Companion to Walt Whitman. Ed. Donald

Kummings. Oxford: Blackwell, 2006. 216-232.

Bohan, Ruth. Looking Into Walt Whitman: American Art, 1850-1920. University Park: Pennsylvania State University Press, 2006.

Burns, Sarah. Painting the Dark Side: Art and the Gothic Imagination in Nineteenth-Century America. Berkeley: University of California Press, 2004.

Burroughs, John. The Heart of Burroughs's Journals. 1928. Ed. Clara Barrus. Port Washington: Kennikat Press, 1967.

Brownell, William C. “The Art Schools of Philadelphia”, Scribners' Monthly 18 (1879): 737-750. 
Dana, Charles. "New Publications: Leaves of Grass." New York Daily Tribune, 23 July, 1855: 3-4. Eakins, Thomas. The Paris Letters of Thomas Eakins. Ed. William Homer. Princeton: Princeton University Press, 2009.

Folsom, Ed. “Whitman Naked?: A Response.” Walt Whitman Quarterly Review 15 (1997): 33-35. ---. "What Do We Represent? Walt Whitman, Representative Democracy and Democratic Representation." Fifteenth Annual Presidential Lecture presented at the University of Iowa. Iowa City, 1998.

Goodrich, Lloyd. Thomas Eakins: His Life and Work. New York: AMS Press, 1933.

Griffin, Randall. Homer, Eakins, \& Anshutz: The Search for American Identity in the Gilded Age. University Park: Pennsylvania State University Press, 2004.

Henry, Barbara. Walt Whitman's Faces: A Typographic Reading. Jersey City: Harsimus Press, 2012.

Homer, William I. Thomas Eakins: His Life and Art. New York: Abbeville Press, 1992.

Johns, Elizabeth. Thomas Eakins: The Heroism of Modern Life. Princeton: Princeton University Press, 1991.

--, "Swimming: Thomas Eakins, the Twenty-Ninth Bather." In Thomas Eakins and the Swimming Picture. Ed. Doreen Bulger. Fort Worth: Amon Carter Museum, 1996.

Locke, John. Second Treatise of Government. 1690. Ed. Richard H. Cox. Hoboken: John Wiley \& Sons, 2014.

Nead, Linda. The Female Nude: Art, Obscenity and Sexuality. Routledge: London, 1992.

Parker, Alison M. Purifying America: Women, Cultural Reform, and Pro-Censorship Activism, 1873-1933. Urbana: University of Illinois Press, 1997.

Peirce, Charles S. The Collected Papers of Charles Sanders Peirce. Ed. Paul Weiss. Cambridge: Harvard University Press, 1974.

Porter, Roy. The Cambridge Illustrated History of Medicine. Cambridge: Cambridge University Press, 1996.

Power, Edward J. Educational Philosophy: A History from the Ancient World to Modern America. New York: Garland Publishing, 1996.

Reynolds, David. Walt Whitman's America: A Cultural Biography. New York: Vintage Books, 1995.

Sewell, Darrel. Thomas Eakins. New Haven: Yale University Press, 2001.

Stovall, Floyd. The Foreground of Leaves of Grass. Charlottesville: University of Virginia Press, 1974

Tarbell, Roberta K. Walt Whitman and the Visual. Arts. New Brunswick: Rutgers University Press, 1992.

Updike, John. Still Looking: Essays on American Art. New York: Alfred A. Knopf, 2005.

Werbel, Amy. Thomas Eakins: Art, Medicine, and Sexuality in Nineteenth-Century Philadelphia. New Haven: Yale University Press, 2008.

White, William. Walt Whitman's Journalism: A Bibliography. Detroit: Wayne State University Press, 1969.

Whitman, Walt. Leaves of Grass. 1855. London: Harper Collins, 2015.

---. Selected Poems: 1855-1892. New York: St Martin's Press, 2013. 
---. "Song of Myself" early manuscript. 1855. Harry Ransom Humanities Research Center, The University of Texas, Austin. Bailiwick, The University of Iowa Libraries. Nov. 8 2016. <http:// bailiwick.lib.uiowa.edu/whitman/specres04.html>

\section{NOTES}

1. A nude involves an allegorical, idealized form of a human figure and as such is not perceived as a transgression of decorum whereas nakedness, a state that follows being stripped bare, implies the unveiling of physicality. To Lynda Nead, "nakedness is a sign of material reality; whereas nudity transcends that historical and social existence and is a kind of cultural disguise" (Nead 16).

2. Eakins was a precursor of realism in visual arts. His interest went beyond the depiction of folklore and everyday scenes of genre painting and aimed at representing things with objective reality. His attempt to scientifically observe the underlying natural forces accounting for a person's likeness can also place Eakins within the naturalist tradition.

3. John Singer Sargent was a contemporary of Eakins. His painterly style was characterized by looser brushstrokes and carefully arranged backgrounds whereas Eakins' realism was more focused on details and stronger compositions. Despite their differences, the two painters admired each other.

4. It seems relevant to coin the term somacratic derived from the Greek -soma, body, and -cratos, power, to refer to the power of the body according to Eakins, a power that was granted by the physicality of the flesh itself and that could lead to democracy.

5. Peirce's theory of signs came in a paper entitled "Some Consequences of Four Incapacities" and was published as early as in 1868. Its impact on Whitman's poetry has never been fully explored so far; only the influence on Whitman of Peirce's pragmatism has been the object of research (see Allison).

6. In a letter to his father written from Paris in 1868, Eakins said: "The French court is become very decent [...] and when a man paints a naked woman he gives her less than poor Nature herself did. I can conceive of few circumstances wherein I would have to make a woman naked but if I did I wouldn't mutilate her for double the money" (Eakins 210).

\section{ABSTRACTS}

In his famous collection of poems Leaves of Grass (1855), Walt Whitman (1819-1892) celebrates the connection between Man and Nature and explores themes of the body. Sensuality and eroticism are also prominently discussed to the degree that his publishers attempted to persuade the poet to remove some sections. Whitman's focus on the body inevitably caused Leaves of Grass to be characterized as reckless and indecent. Whitman's close friend, painter Thomas Eakins (1844-1916) also shared the poet's fascination for the body and was even more vilified by critics for his detailed rendering of the flesh, his unrestrained study of human physiology and his insistence on seeing the human figure as the most beautiful object in nature. His uncompromising realism along with his supposedly indecent teaching caused his dismissal from the Pennsylvania Academy of the Fine Arts. His masterpiece The Gross Clinic (1875) equally caused 
scandal and was described as repulsive and a degradation of art. The critical reactions to the vision of the body Whitman and Eakins shared show the impact of Victorian-age morality. This aesthetic prudery seemed particularly old-fashioned in the age of medical and technological progress and did not fit the strong link to Nature central to American culture from the early $19^{\text {th }}$ century. This study focuses on the similarities in Whitman and Eakins' treatment of the flesh and their mutual efforts to promote a new understanding of corporeality. Although previous research has looked into the connection between the two American artists, this article aims at being a comprehensive study of the social resonance of corporeal matters in Eakins and Whitman's art.

Dans son célèbre recueil de poésie Leaves of Grass, Walt Whitman (1819-1892) fait l'éloge du lien entre l'homme et la nature et explore le champ charnel. L'érotisme et la sensualité des vers ont mené ses premiers éditeurs à tenter de convaincre Whitman de supprimer certaines sections du recueil. L'attention portée à la corporéité a fait qualifier l'ouvrage d'indécent et de malséant lors de sa première parution. Ami proche de Whitman avec lequel il partageait une véritable fascination pour l'anatomie, le peintre Thomas Eakins (1844-1916) fut, en son temps, lui aussi vilipendé pour ses représentations physiologiques détaillées et pour son étude poussée du corps humain, le plus bel objet conçu par la nature selon lui. Son réalisme sans compromis et son enseignement jugé impropre causèrent son renvoi de l'Académie des Beaux-Arts de Philadelphie. Son chef d'œuvre The Gross Clinic (1875) choqua également le public, scandalisé par la nature prétendument irrévérencieuse de son sujet. A travers la critique de la vision du corps que partageaient Whitman et Eakins se lit la persistance d'une moralité victorienne, une pruderie esthétique en opposition avec les progrès technologiques et médicaux de cette époque et une culture américaine qui, dès le tournant du $19^{\text {ème }}$ siècle, prône l'harmonie de l'homme avec la nature. Axée sur le traitement du corps dans l'art de Whitman et d'Eakins, cette étude fait état des similitudes de leurs approches et de leurs efforts mutuels à faire accepter une vision moderne de la chair. Si les rapports entre les pratiques artistiques d'Eakins et de Whitman ont déjà fait l'objet de recherches, cet article porte non seulement sur le croisement du travail des deux artistes mais aussi sur les résonances sociales de leur nouvelle esthétique du corps.

\section{INDEX}

Mots-clés: peinture, poésie, esthétique, Etats-Unis, 19ème siècle, réalisme, corps, intermédialité

Keywords: painting, poetry, aesthetics, United States, 19th century, realism, body, intermediality

\section{AUTHORS}

\section{HÉLÈNE GAILLARD}

Maître de conférences, Université de Bourgogne

Centre Interlangues TIL (Texte, Image, Language) EA 4182

helene.gaillard@u-bourgogne.fr 